\title{
河川植生の分布とその調査方法 に関する基礎的解析 \\ FUNDAMENTAL EXAMINATION ON METHOD OF FIELD SURVEY OF DISTRIBUTION OF VEGETATION IN RIVER
}

\author{
砂田憲吾 1 ・白石孝幸 ${ }^{2} \cdot$ 岩本 尚 ${ }^{3}$ \\ Kengo SUNADA, Takayuki SHIRAISHI and Hisashi IWAMOTO \\ 1正会員 工博 山梨大学教授 工学部土木環境工学科（テ400-8511 甲府市武田四丁目3-11） \\ 2正会員 建設省近畿地方建設局 福井工事事務所（广918-8015 福井市花堂南二丁目 14-7） \\ 3正会員 工修 東京電力株式会社 葛野川水力建設所（广409-0621 大月市七保町瀬戸1646）
}

\begin{abstract}
The vegetation in river is one of the most important conditions concerning the river environment. It is needed to establish an appropriate method of the field survey for getting conditions of distribution of vegetation from view points of management of river environment. In this study, an efficient method of the vegetation survey was examined. Based on the review on characteristics of distribution of vegetation, the detail vegetation survey was conducted in the upper part of the Fuji River first. Feature of vegetation distribution in the river was discussed in the next. Then scale of gathering the detail data were aggregated successively, then reasonable minimum scale of the survey was investigated. An appropriate spatial scale in the vegetation survey was exemplified.
\end{abstract}

Key Words : river environment, vegetation in river, vegetation survey, Fuji River

\section{1.はじめに}

河川植生は河川の流況に直接関与すると共に, 河道内 外の各種生物の生態環境を提供している. このため, 河 道の管理および河川環境管理の立場から，その形態や分 布およびそれらの変化を把握する努力がなされ，多くの 現地調査が行われてきている．建設省は1990年以来「河 川水辺の国勢調査」として, 河川に生息する魚介類, 底 生動物等の調查と並んで植物調査を実施している こでは, 植物生態学的な観点を導入し網羅的かつ詳細な 植物調查の結果が蓄積され，河川環境の基本的な資料が 得られている. しかしながら，この資料は主に植生の平 面的な分布を図面等に展開したいわばアナログ形式で示 されており，そのままでは河道の管理や計画のために定 量的な評価を進める上では最適ではない，植生の存在状 態を河川の管理に直接反映し得る情報が必要で，そのた めの調査や資料が求められている.

上記の点に関して，最近では植生分布と河道の特性と の関係を議論する調查研究が進められている2,33,4),5). そ れらの結果と最近精力的に進められてきた河川水理学々 の融合を目指したレビューも示されている6).さらに,
河川環境管理財団では，流域，河道，局所流況の各ス ケールでの視点から，河川の管理のために現場実務にも 用いられるべき簡潔な調査方法を提示している7). 一方, 辻本 ${ }^{6)}$ は植生調查の結果をその後の解析に利用しやすく するためにメッシュ形式のデータ作成を提案しており， 有効な方法と考えられる.この場合，多様で広大な河道 にあって，詳細な調査であるほど有効な調査であるとは 限らない，目的に応じた調査の合理性と調査方法の改善 が目指されるぐきである。

本研究では, 植生分布の基本的な条件を得るために, 新たに実河川での詳細な植生調查を実施した. その結果 に基づいて植生の分布特性の把握とメッシュデータ作成 のための空間的な基準スケールに焦点をあてて基礎的な 解析を行った.

植生調査に関する基本的考え方 : 植生の分布を把握す るためにはさまざまな観点がある．群落の生態，貴重種， 景観，物理的な構造ほかが考えられるが，ここでは，そ の種の植物の存在・繁茂機会・立地条件に注目し，「各 種の植物は例外なく立地条件に応じて存在 (分布) して いること」を前提とする. それを表現し得る最適のデー 夕取得間隔 (空間スケール・解像度) を検討することと した. このスケールは本来，コドラート調查における面 


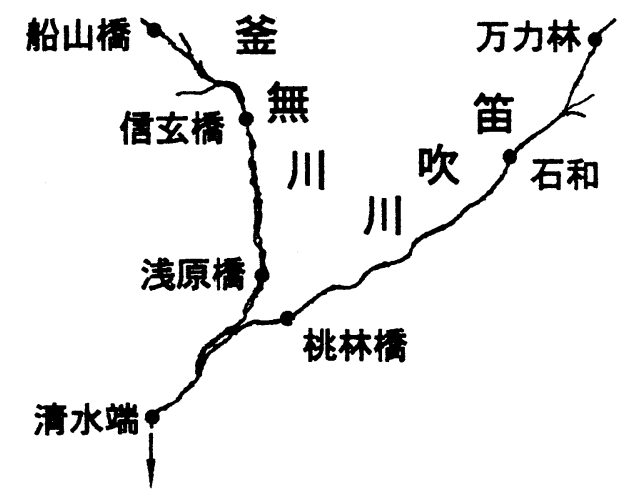

図-1 富士川調査対象区間・地点位置関係図

積のように，群落の種類の応じて設定すべきであるが， 可能な最小単位でデー夕取得をしておくことの方がむし ろ便利でもある. さらに, ベルトトランセクタによる調 査およびそれらの基準にも有効と考えられる.ささらに発 展的な調查方法として, 航空機や衛星によるリモートセ ンシングデータの利用の点においても，根拠のある基準 スケールを必要解像度として提案できるものでもある.

考察対象は富士川上流部の本川釜無川，支川笛吹川の 代表地点である. 対象地点では後述するように, 典型的 な扇状地河川であり, これまでに植生域の変化, 河道特 性が詳しく調査されてきている.

\section{2. 植生分布と立地条件}

本研究ではまず植生の立地条件をより的確に評価でき る指標について吟味する必要があり，これまでの調査結 果)を再整理してみる.

筆者らはこれまでに，図-1に示す富士川上流部本川 $25 \mathrm{~km}$ (船山橋一清水端間)，支川笛吹川 $26 \mathrm{~km}$ 区間（万力 林一合流点間) を対象として, 植生分布の状況の平面的 な流下方向の特徵と, 植物種別の鉛直方向の分布形態と の関係を調べている. 前者では植生の繁茂機会と河道特 性, 特に 1 次元的な断面平均水理量との関係を見出すこ
とを目的とした. すなわち, 何らかのかたちで, 植生の 分布たとえば植生種別の繁茂面積などが河道の平均的な 特性と関係付けられれば, 将来の植生の存在や遷移の傾 向を予測できると考えたからである.

植生の流下方向の分布の検討では, 河川水辺の国勢調 査による「現存植生図」が用いられた. $1 \mathrm{~km}$ 区間ごとに 形態別に分けられた21種類の植生別面積率と河道特性と の関係を調べた. 河道特性には断面平均量を用いて次元 解析加ら求まる無次元水理量 (河幅水深比 $(\mathrm{B} / \mathrm{H})$, 河 床粒径水深比 $(\mathrm{d} / \mathrm{H}), \mathrm{Fr}$ 数, Re数, 無次元掃流力 $\left.\left(\tau_{*}\right)\right)$ および低水河道の固定効果を加味して河道の 湾曲度 $(\mathrm{r})$ を考慮した. 個別の具体的な関係の程度は はここでは省略するが，植種により影響を受ける無次元， 量が異なることが知れた。結果を集約すると表-1, 表-2 にのようになる，表の $\mathrm{A}_{\mathrm{i}}$ は各植種の面積率を示し，例 えば $A_{17}$ は荒れ地草本性植物群落の面積率を表す。これら の表から, 各植種の分布に影響する河道との特徵的な関 係が二つの河川で異なっており, 植生の繁茂がここで抽 出された河道特性のみで一義的に評価し得ないことを表 している.

一方, 辻本ら ${ }^{2}$ は植物の分布の特徵に水面からの比高 が影響することを指摘している. 富士川においても，前 述の資料をもとに, 同じ要素区間内の植生面積 $\left(\mathrm{A}_{\mathrm{i}}\right)$ と 各断面における水位（例えば渴水位）からの比高との関 係を調べた. 比高は同一植種が分布する領域の最低比高 と最高比高の範囲で考えることとした. 結果の一例とし て荒れ地草本性植物群落の場合, 図一2のようであった. チガヤのように分布と比高との関係が明瞭ではない植種 も一部あったが，多くの植種は図-2に示されるように, 水辺周辺で繁茂する面積は小さく, 水辺から高く離れる と面積は減少し, その中間の高さで面積は最大をとるよ うである. 同時に川辺樹林の分布についても調べられた が，釜無川，笛吹川で分布の範囲は異なるものの推定さ れる堤内側の地下水位との関係から類推される傾向と一 致し, 樹林の場合も水面からの比高に影響されることが 追認されている.

表-1 種別の植生面積率（Ai）と河道水理特性量との関係（釜無川） ${ }^{4)}$

\begin{tabular}{|c|c|c|c|c|c|c|c|c|c|c|c|c|c|c|c|c|c|c|c|c|c|}
\hline$A i$ & 1 & 2 & 3 & 4 & 5 & 6 & 7 & 8 & 9 & 10 & 11 & 12 & 13 & 14 & 15 & 16 & 17 & 18 & 19 & 20 & 21 \\
\hline $\mathrm{Fr}$ & . & $x$ & 0 & & $x$ & $x$ & & $x$ & $\Delta$ & $x$ & $\times$ & $\Delta$ & $x$ & $x$ & $\Delta$ & $x$ & 0 & $x$ & $x$ & $x$ & $\Delta$ \\
\hline $\mathrm{B} / \mathrm{H}$ & $x$ & $\Delta$ & 0 & & $x$ & $x$ & 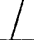 & $x$ & $\Delta$ & $x$ & $\times$ & 0 & $x$ & $x$ & $x$ & $x$ & 0 & $x$ & $x$ & $x$ & 0 \\
\hline$\tau$. & $x$ & $x$ & $\Delta$ & & $x$ & $x$ & & $x$ & $\Delta$ & $x$ & $x$ & 0 & $x$ & $x$ & $x$ & $x$ & 0 & $x$ & $x$ & $x$ & $\Delta$ \\
\hline $1 / r$ & $x$ & $x$ & $\Delta$ & & $x$ & $x$ & & $x$ & $\Delta$ & $x$ & $\Delta$ & $x$ & $\Delta$ & $\Delta$ & $\Delta$ & 0 & $\Delta$ & $x$ & $x$ & $x$ & 0 \\
\hline
\end{tabular}

表-2 種別の植生面積率（Ai）と河道水理特性量との関係（笛吹川）

\begin{tabular}{|c|c|c|c|c|c|c|c|c|c|c|c|c|c|c|c|c|c|c|c|c|c|}
\hline $\mathrm{Ai}^{-}$ & 1 & 2 & 3 & 4 & 5 & 6 & 7 & 8 & 9 & 10 & 11 & 12 & 13 & 14 & 15 & 16 & 17 & 18 & 19 & 20 & 21 \\
\hline $\mathrm{Fr}$ & & & $\Delta$ & $x$ & & & & & $\Delta$ & & $x$ & $x$ & $x$ & $x$ & 0 & $\Delta$ & $x$ & $\Delta$ & $x$ & $x$ & 0 \\
\hline $\mathrm{B} / \mathrm{H}$ & & & $\Delta$ & $x$ & & & 7 & I & $x$ &  & $x$ & $x$ & $x$ & 0 & $\Delta$ & $x$ & $x$ & $x$ & $x$ & $x$ & 0 \\
\hline r. & & 1 & $x$ & $x$ & & 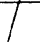 & 1 & 7 & $\Delta$ & 7 & $x$ & $x$ & $x$ & $\Delta$ & $x$ & $x$ & $x$ & $\Delta$ & $x$ & $x$ & 0 \\
\hline $1 / r$ & & & $x$ & $x$ & & & & & $x$ & & $x$ & $x$ & $x$ & $x$ & $x$ & $x$ & $x$ & $x$ & $x$ & $x$ & $\Delta$ \\
\hline
\end{tabular}

○…加な関係あり

○一関係的

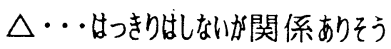
$\times \cdots$ 無関係 


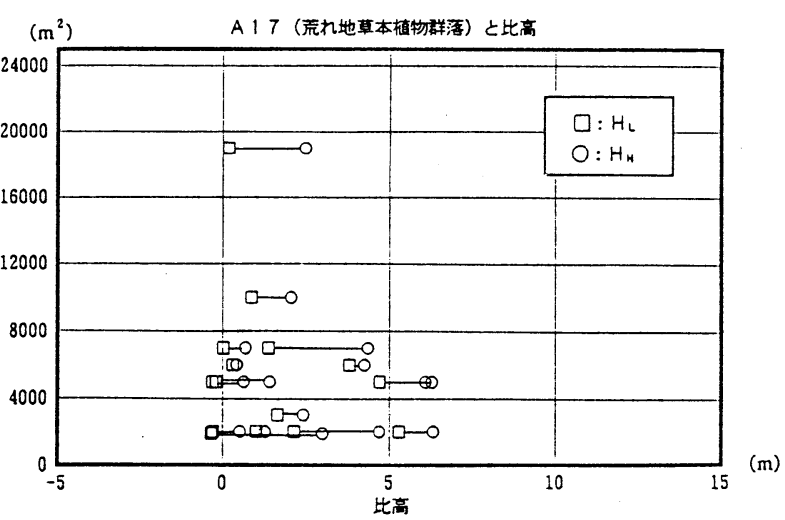

図-2 荒れ地草本性群落の面積と比高の関係 ${ }^{4)}$

\begin{tabular}{|c|c|c|c|}
\hline & 凡 & 例 & \\
\hline & 川 川躈 & & カワナナギ \\
\hline & 滔 & & 久久 \\
\hline 80 & 傥诰物 & hint & $\exists モ キ$ \\
\hline & ハீ & & 于 $f^{\prime}+$ \\
\hline$\therefore$ & 棑 俳地 & & シナダレススイガけ \\
\hline & $\exists$ & & ズ \\
\hline & キ & What & 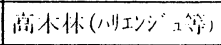 \\
\hline & ツ ル $ヨ$ シ & & 裸 \\
\hline
\end{tabular}

図-3 植生分布の凡例

\section{3．詳細調査と植生の分布}

\section{（1）植生調査}

前節の考察に基ついて，植生の分布と水面からの比高 との関係をあらためて把握するために，図一1に示される 釜無川 2 地点 (信玄橋, 浅原橋)，笛吹川2地点（石和. 桃林橋) の計 4 地点で詳細な植生調査を行った。これら の地点は，付近で水位観測も行われ，別途実施中の植生 長期観察対象としている地点でもある.

それぞれの地点で流下方向に約 $200 \mathrm{~m}$ ，全川幅に対し辻 本ら ${ }^{2)}$ の提案する河川植生調査法に基づいて植物調查と 河道の微地形調査を行った. 釜無川・笛吹川ともの今回 の対象地点では高低差が小さく，流量変化が多いことか ら 1 多年生の草本類が多く繁茂している.

対象の 4 地点のうち, 浅原橋では結果的に砂裸地が多 く分布の検討には有効ではないこと，桃林橋では植生の 種類が少ないことから，ここでは信玄橋，石和地点での 調査を中心に考察する.

調査ではまず微地形の変化点. 植生の変化点のすべて を計測した. 次に, 踏査時に得られた植生分類データ

（図-3）と照らし合わせて植生の種別の境界線を引き， 図-4，図-5のように色分けして表示する．同図には微地 形も示されている.この資料をもとに5mメッシュをかけ て地形データ，植生データを内挿して表す．各メッシュ では優先種を代表して収録する。

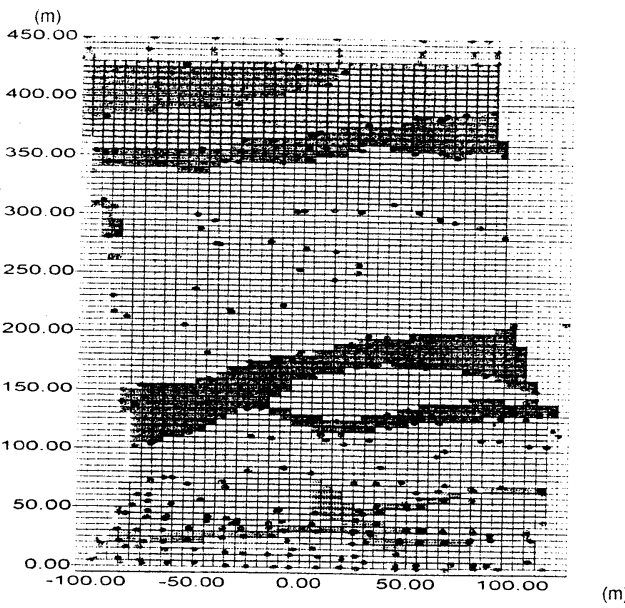

(a) 植生分布図

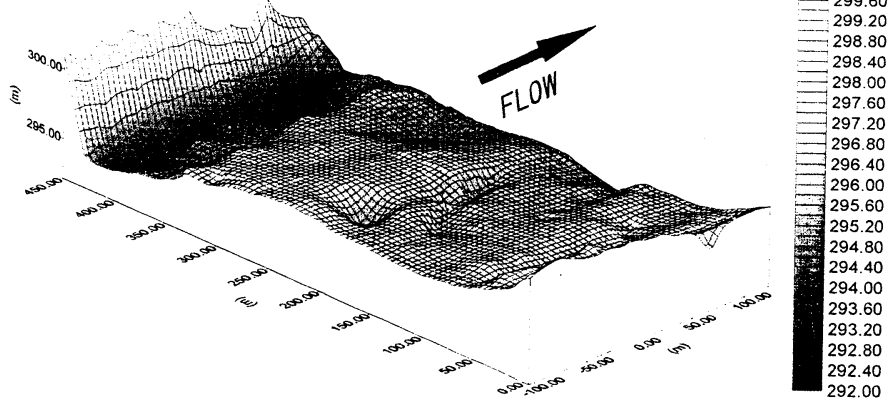

(b) 地形図

図-4 植生分布と河道地形 (信玄橋)
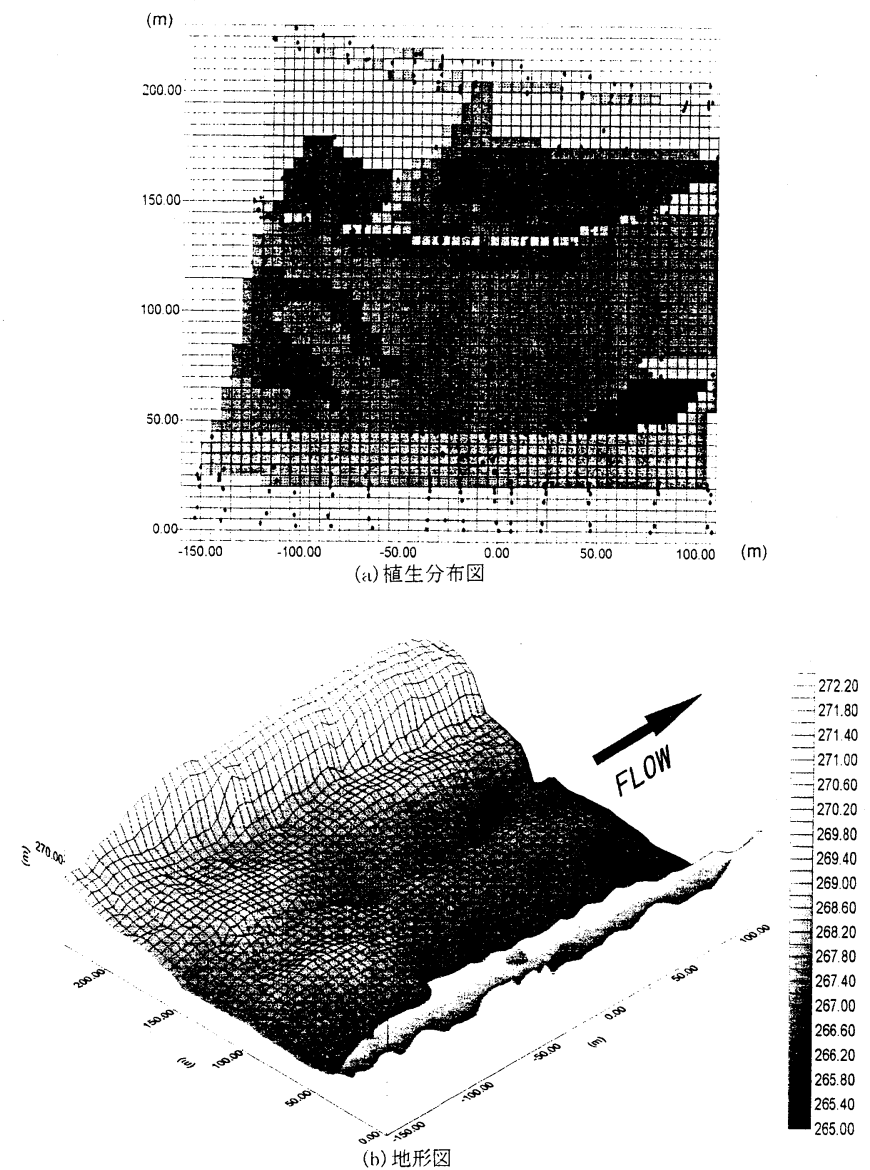

図-5 植生分布と河道地形 (石和) 


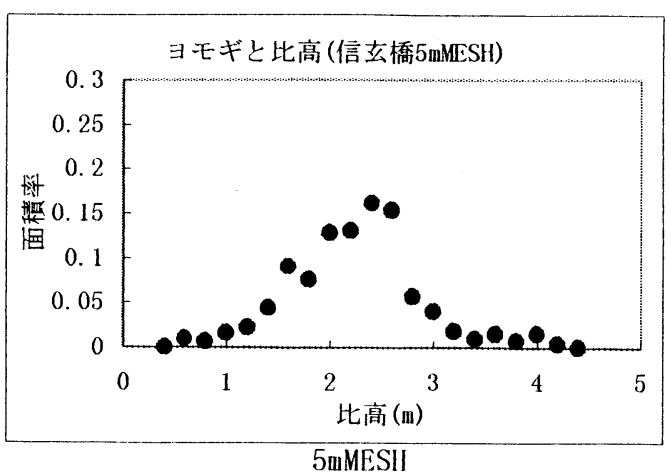

(a)

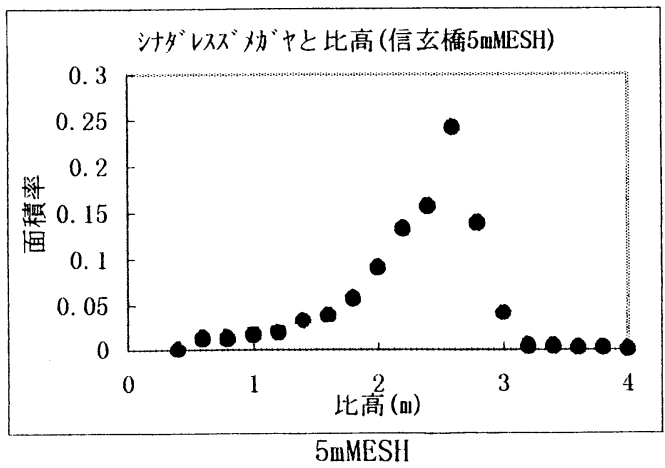

(c)



(e)

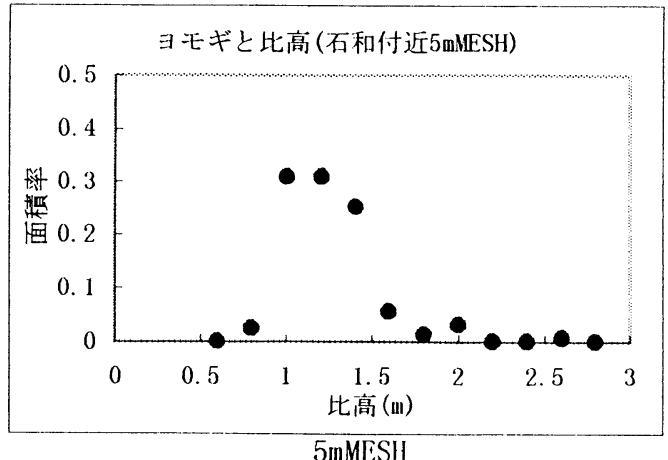

(b)

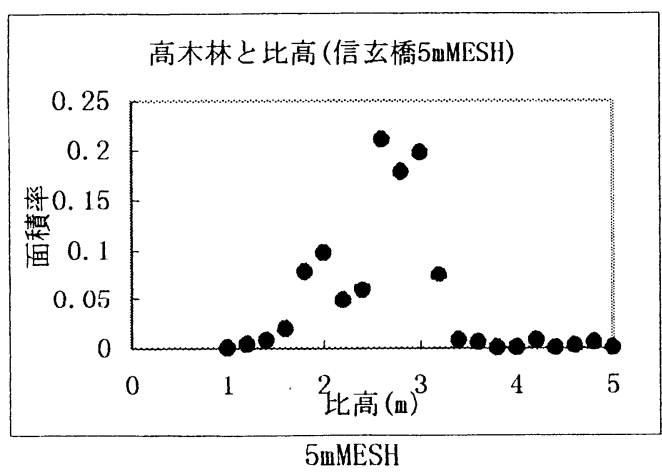

(d)

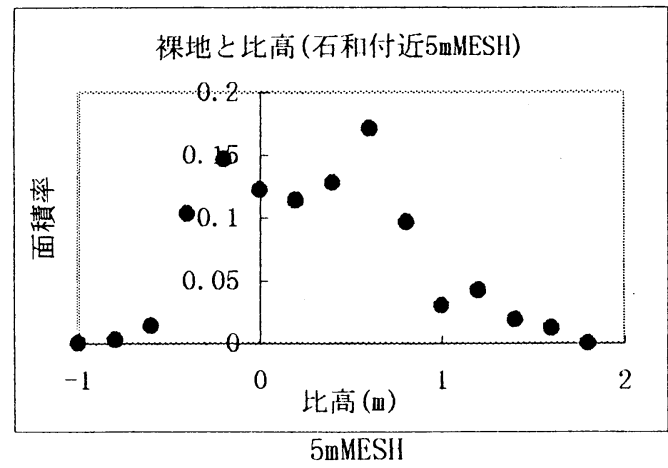

(f)

図-6 植生の分布の特徴

\section{（2）植生分布}

それぞれの地点での $5 \mathrm{~m}$ ッシュデータをもとに, 植生 の分布の特徵を調べた.

図-6(a)，(c)，(d)，(e) は信玄橋における代表的な植生 の面積率と比高の関係, 図一(b), (f) は石和におけるヨ モギ. 裸地と比高との関係を示している．比高の基準と なる河川水位としては, 植生調査当時の水面標高をとっ ており，後の調べからその水位はほぼ低水位に近いこと が知れている.

ヨモギについては，両地点での分布の特徵を見ると， まず両河川で最大の面積率を持つ比高には水位の変動も 関係し若干の相違があることが分かる. また，釜無川で
は河道内の流路の変動に伴う高低差のために広い範囲に ヨモギが分布しているのに対し，笛吹川では交互砂州の 形成による比較的単調な横断面形のため繁茂の比高が集 中していることも知れる.

図-6 (c) のシナダレスズメガヤは荒れ地に多く存在 する植生で, 今回の調査からも比高の比較的高い，水の 影響の受けにくい位置に広く分布していることがわかる. 図一 (d) に示す高木林は左右岸の微高地に存在している 結果を反映している.

図一(e)，(f)は両地点の裸地の分布状態を示している. 裸地は植生そのものではないが，逆の視点から，植生が 繁茂できない，出水時に破壊されやすい場所を示してい ることになる. 同図から両地点, 特に信玄橋での結果で 



図-7 メッシュサイズの拡大によるデータの平均化（信玄橋）

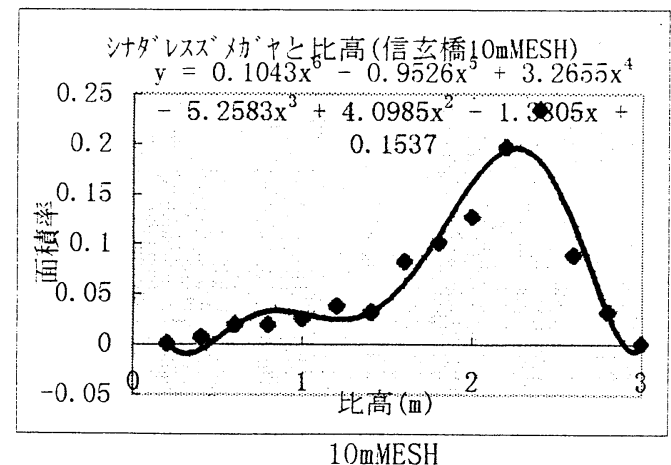

(a)

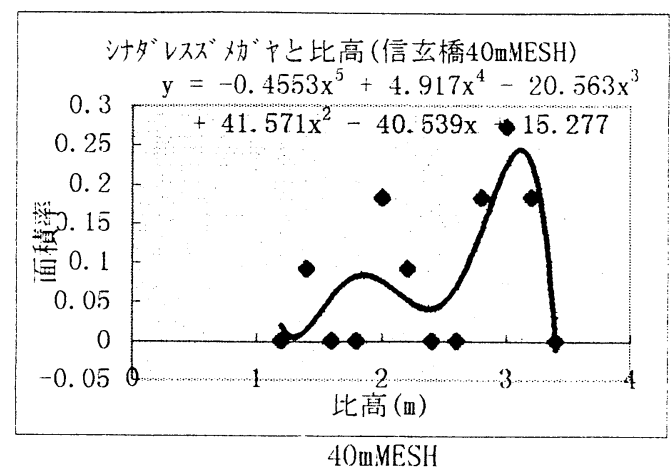

(c)

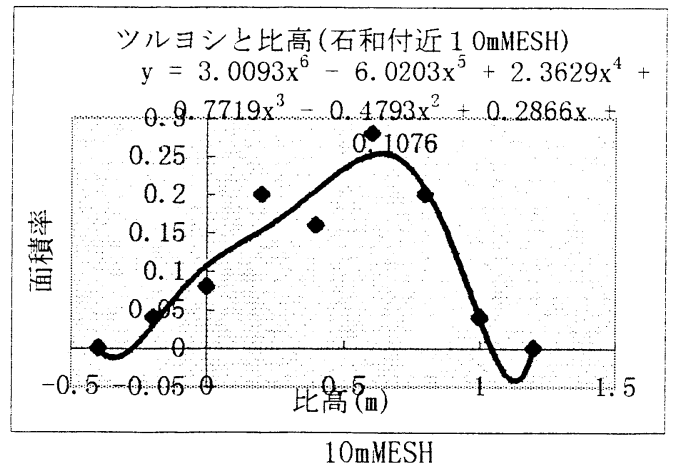

(b)

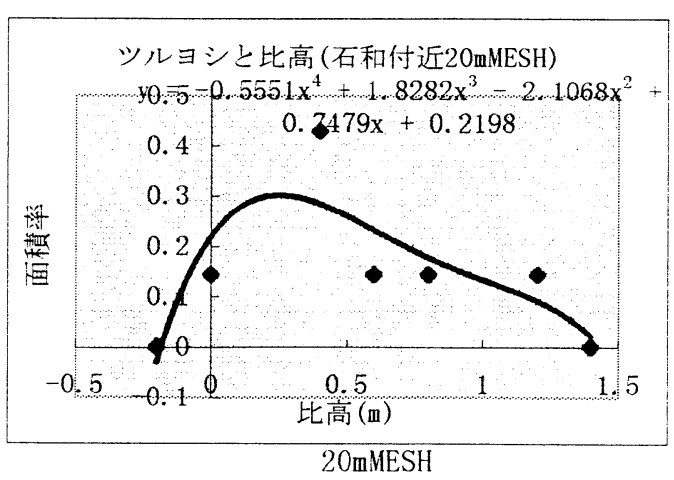

(d)

図-8 植生別分布回帰曲線のあてはめ

は比高に対する面積率に二つの極大点が生じているが， それらは中小洪水時の流路およびより大きい洪水時の流 路に対応する面積率の分布となっている. このことより, 植生の消長 ・予測を考える上で裸地の中長期的な分布状 態の把握が有効であると考えられる.

\section{4.メッシュサイズの拡大と植生分布の表現性}

これまでの研究では，岡部ら ${ }^{5}$ が交互砂州上の植生調 査しに基づいて, 河状の履歴特性により群落分布の回帰 モデルを構成するために基隻スケールを検討している. 目的は異なるが岡部らにならい，空間的な平均化を行う メッシュスケールの拡大と共に植生分布の評価がどのよ うに変化するかを調べた。

(1) メッシュの拡大

それぞれの地点ごとに，5mメッシュデータを基本に，さ 


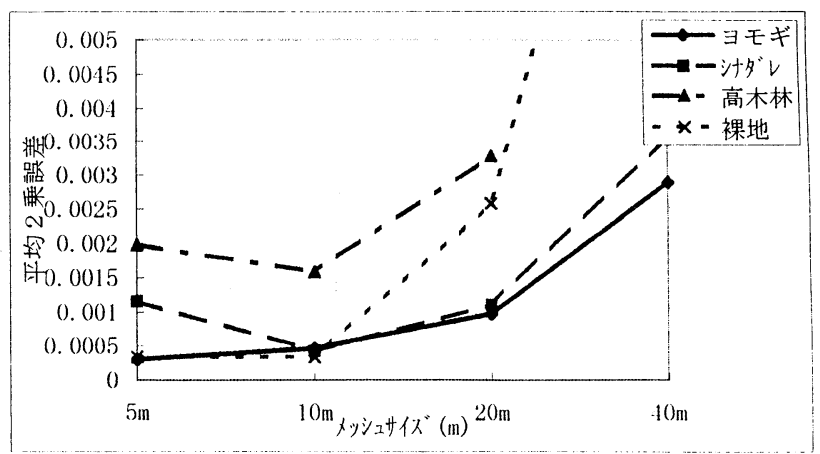

（a）信玄橋

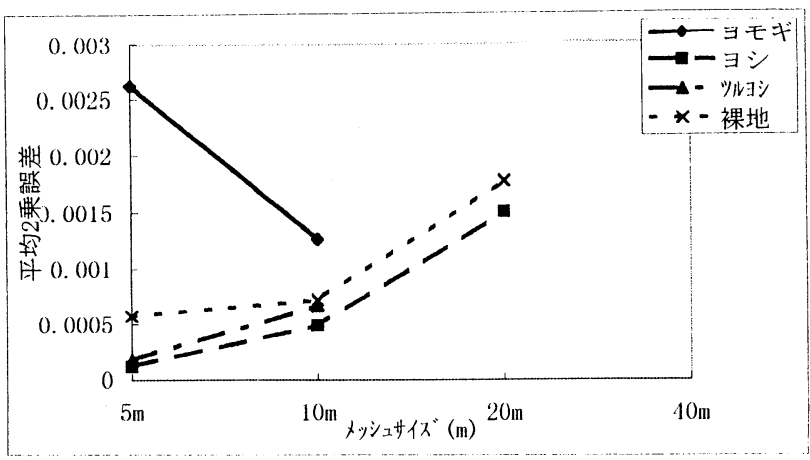

(b) 石和

図-9 メッシュサイズと回帰曲線の近似度

らに，10m，20m，40mのメッシュをかけ同様に整理した. 例えば，40mのメッシュデータは5mのメッシュデータの 面積率を用いて該当する拡大メッシュの中で最優勢な種 を配置するようにして作成した。

図一７は信玄橋地点におけるメッシュの拡大による データの平均化の様子を示している.

\section{（2）回帰曲線による近似表現の程度とメッシュサイ ズ}

それぞれのメッシュサイズによる分布データを用い， 植種ごとの面積率と比高との関係を多次式で回帰曲線を 求める. すなわち各メッシュサイズに対して，比高によ る 1 次から 6 次までの回帰曲線をあてはめ, そのうちの 最もフィットする次数を調へ，最適な回帰曲線を求めた。

図-8 は各メッシュサイズごとに植種の分布を近似的 に表示するものである.（c）図の信玄橋でのシナダレ スズメガヤの40mメッシュでは明らかに分布が抽出でき ない. (d) 図の石和でのツルヨシも20mメッシュでは 10mの場合と傾向が変わっており, 近似度も低下する.

各植種, 各メッシュスケールでの近似曲線の中で最適 な近似曲線の表現度合いとして 2 乗平均誤差を調べると 図-9のようになる.より大きなメッシュスサイズでは データ数の減少により, 評価が不適になる場合もあるが, 各植種に共通した特徵が見いだせる. 同図によると, 信 玄橋では20m以下のメッシュが，石和では10m以下のメッ シュで植生分布特性を抽出できると考えられる.これら を総括すれば，調查の基準スケールとして10mを考慮す ればよいことになる.

\section{5. おわりに}

富士川上流部本川・支川の代表地点で，新たに実施さ れた詳細な植生調查に基ついて, 植生の分布と調査基準 スケールについて検討を行った. 植生分布では, 砂州も
しくはそれに応じた一次的, 二次的な澪筋に対応して草 本類の分布が定まっており，裸地面の分布もそのことを 反映している. 調査の範囲で, 基準スケールは種々の植 生に対して10mが得られた。このスケールは植生の種に 共通しているので今後の適用に都合がよい. ここでの取 り上げられなかったより多くの植生に対しては, 今後, 各河川で同様な解析を行い，結果の蓄積が進むことを期 待している.

謝辞 : 本研究の一部は（財）河川環境管理財団・河川整 備基金の助成をうけて実施されたもので，記して深く感 謝いたします．現地調査に側面からご協力を頂いた建設 省甲府工事事務所に厚くお礼申し上げます。

\section{参考文献}

1) たとえば，建設省河川局河川環競課：河川水辺の国勢調査マ ニュアル，河川版（生物調查編）平成 9 年版, 1997.

2) 辻本哲郎, 岡田敏治, 村瀬 尚 : 扇状地河川の川原の植物群 落と河道特性 - 手取川における調查 - , 水工学論文集, Vol. 37, pp. 207-214, 1993.

3) 宇田高明, 藤田光一, 佐々木克也, 服部 敦, 平舘 治: 河 道特性による植物群落の分類 - 利根川と鬼怒川を実例とし て - ，土木研究所資料，第3249号，1994.

4) 砂田憲吾, 岩本 尚, 松崎 実: 河川植生の水平 - 鉛直分布 と河道特性に関する調查解析, 水工学論文集, Vol.40, pp.193-198, 1996.

5) 岡部健士, 鎌田磨人, 湯城豊勝, 林 雅隆 : 交互砂州上の植 生と河状履歴の相互関係 - 吉野川における現地調查, 水工 学論文集, Vol. 40, pp. 205-212, 1996.

6)（財）河川環境管理財団：河川の植生と河道特性，河川環境 総合研究所資料第 1 号, 1995.

7）(財）河川環境管理財団: 河川管理のための植生の調査方法, 河川整犕基金事業報告書, 1996. 